\title{
Geochemistry of feldspar and muscovite from pegmatite of the Gatumba area, Karagwe Ankole Belt: implications for $\mathrm{Nb}-\mathrm{Ta}-\mathrm{Sn}$ mineralisation and associated alterations
}

\author{
Jean de Dieu Ndikumana ${ }^{1,2}$. Anthony Temidayo Bolarinwa ${ }^{1} \cdot$ Gabriel Oladapo Adeyemi $^{1} \cdot$ Jerry Olajide-Kayode $^{1}$. \\ Claude Nambaje ${ }^{3}$
}

Received: 1 April 2020 / Accepted: 19 August 2020 / Published online: 27 August 2020

(c) Springer Nature Switzerland AG 2020

\begin{abstract}
The studied pegmatites suggest a sodium-dominant pegmatitic melt where micas and albites are dominant over potassium minerals. The mapped pegmatites from the Gatumba area are of interest in Karagwe Ankole Belt for the study of rare-element pegmatites. Previous works on the Gatumba pegmatites included geochemistry and geological mapping; and further studies are required for focused exploration and mine planning. For this reason, field investigation, petrographic and mineral chemistry studies on pegmatites were carried out. Thin sections of the rock samples collected were studied under a transmitted light microscope. Electron Microprobe Analysis and Energy Dispersive X-Ray Spectroscopy were used for mineral chemistry and identification; Back Scattered Electron analysis was used for mineral texture. Major minerals identified in the pegmatite bodies are quartz, plagioclase and micas. Albites $\left(\mathrm{An}_{0.1-0.8} ; \mathrm{Ab}_{98.7-99.6}\right.$ and $\left.\mathrm{Or}_{0.3-0.5}\right)$ are found as the dominant-plagioclase minerals in the pegmatites from the Gatumba area. Albites are precursors to kaolinites, and the albitisation and kaolinisation processes altered the primary emplaced pegmatites during the mineralisation of the $\mathrm{Nb}-\mathrm{Ta}$, $\mathrm{Sn}$ rare metals, which precipitated into columbite-tantalite and cassiterite. Muscovites are the most common mineralogical indicators of strongly peraluminous composition in plutonic rocks. Crystallisation, muscovitisation and kaolinisation accompanied the precipitation of prompted cassiterite and columbite-tantalite in the pegmatites of the study area.
\end{abstract}

Keywords Mineral chemistry · Alteration · Pegmatite · Gatumba

\section{Introduction}

Karagwe Ankole Belt (KAB) in the east-central Africa is defined as an orogenic belt of Mesoproterozoic units, mostly composed of a sequence of pelitic and carbonate sediments with minor metavolcanic rocks intruded by major felsic and subordinate mafic rocks [1]. KAB together with Kibara Belt (KIB) in the South-West of the $K A B$ host a large number of granite-related metal deposits mainly $\mathrm{Sn}-\mathrm{W}-\mathrm{Nb}-\mathrm{Ta}$ ore deposits $[2,3]$. The metals are dominantly hosted in pegmatites or quartz veins. According to [4], the pegmatites of the KAB can be found mineralised with $\mathrm{Nb}$-Ta minerals, and cassiterite with accessory minerals such as amblygonite, spodumene, beryl, apatite and tourmaline while mineralised quartz veins mainly contain cassiterite or wolframite. These primary mineralisations observed in quartz veins, greisens and pegmatites are also found in placer deposits as secondary mineralisations. The petrogenetic studies of pegmatites from the parental granites and their defined zonation have been

\footnotetext{
$\triangle$ Jean de Dieu Ndikumana, jndikumana0245@stu.ui.edu.ng | ${ }^{1}$ Department of Geosciences, Pan African University, Life and Earth Science Institute, University of Ibadan, Ibadan, Nigeria. ${ }^{2}$ Department of Mining Regulation and Inspection, Rwanda Mines, Petroleum and Gas Board, Kigali, Rwanda. ${ }^{3}$ Centre for Earth Sciences, Indian Institute of Science, Bangalore, India.
} 
previously done [5]. However, there is not enough documentation on the geochemical and mineralogical characterisations of the pegmatites and associated rocks, and the processes that occurred during and after the primary emplacement of the ores. Geochemistry of tin and niobotantalum bearing pegmatites and greissen deposits show a close spatial association with highly evolved peraluminous S-type granitic massive rocks [2]. According to [2], the pegmatites from Gatumba to Gitarama (G\&G) areas of the $K A B$ have high contents of specific rare elements $(F, R b, L i$, $\mathrm{Sn}, \mathrm{Be}, \mathrm{W}$ and $\mathrm{Mo}$ ) relative to normal granites. They may also have higher concentrations of $\mathrm{B}, \mathrm{Nb}, \mathrm{Ta}, \mathrm{U}, \mathrm{Th}$ and REE. Mineralised pegmatite is usually enriched in $\mathrm{Li}, \mathrm{F}, \mathrm{Rb}, \mathrm{B}$ and $\mathrm{Be}$, and contains sulfide and sulfosalt minerals such as $\mathrm{Cu}$, $\mathrm{Pb}, \mathrm{Zn}, \mathrm{Bi}, \mathrm{Ag}, \mathrm{As}$ and $\mathrm{Sb}$. The sulfur and heavy metal contents are usually small. Our study focuses on the textures and mineral compositions of the pegmatites to evaluate their petrogenesis and processes that occurred during and after the primary emplacement of ores. We address this through field investigation, petrography, energy-dispersive $X$-ray spectroscopy and mineral chemistry analyses of pegmatite samples from the Gatumba area of the KAB, Rwanda.

\section{Geological settings}

\subsection{Regional geology}

The regional geology, structural settings, stratigraphy and metamorphism in the Kibara orogen are well documented by previous authors $[6,7]$. KIB and KAB of east-central
Fig. 1 Simplified map representing the regional geology and settings of the Karagwe Ankole Belt (KAB) and Kibara Belt (KIB) of east-central Africa (modified after [1])

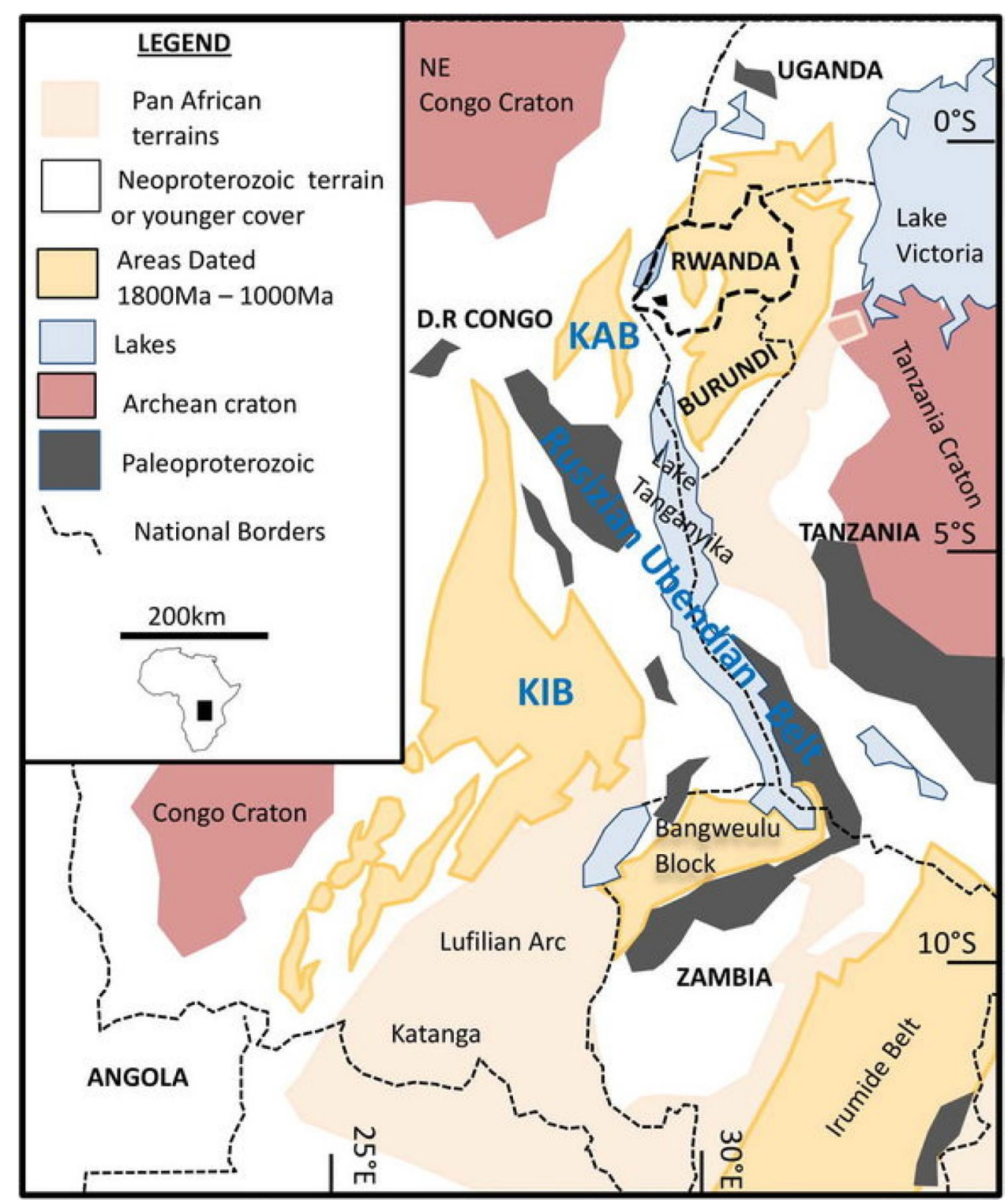


Africa together form and evolve between two pre-Mesoproterozoic domains: The Archaean Tanzania Craton to the East, the Archean to Paleoproterozoic Congo Craton to the west and north, and Bangweulu block to the south [1]. Both belts are separated by the Paleoproterozoic RusizianUbendian Belt (Fig. 1). They host two main granite generations with the old granite dated at $1375 \pm 10 \mathrm{Ma}$ and younger granite at $986 \pm 10 \mathrm{Ma}$ [7]. The latter is related to ore deposits of typical $\mathrm{Nb}-\mathrm{Ta}-\mathrm{Sn}-\mathrm{W}$ metal association in the pegmatites or quartz veins [8]. Pegmatites can be found predominantly mineralised in $\mathrm{Sn} / \mathrm{Nb}$-Ta minerals namely cassiterite and columbite-tantalite while quartz veins are found to be mineralised in Sn/W minerals including cassiterite or wolframite. The primary mineralisation was observed in quartz veins and pegmatites, but also as secondary mineralisation in alluvial/eluvial deposits [8].

\subsection{Geology of the study area}

The Gatumba area is situated in the west part of Rwanda (Fig. 2), about $50 \mathrm{~km}$ west of Kigali. The Gatumba area is considered as an interesting area for the study of pegmatites and related mineralisation in the KAB [9]. The defined zonation of pegmatite from Gitarama towards the
Gatumba mine concession has been characterised by the presence of frequent rare-element pegmatites [10]. The zoned pegmatite is variably mineralised in columbite-tantalite and/or cassiterite with accessory minerals, including apatite, beryl, spodumene, tourmaline, amblygonite and rare phosphate minerals. The Gatumba area consists of Mesoproterozoic rocks, which belong to the lithostratigraphic Akanyaru Supergroup [1]. The lithostratigraphic map of the Gatumba area combined with the geological map of Rwanda after [11] indicates the study area extends to Gikoro, Pindura and Cyohoha groups. The Gatumba area is situated between two granitic bodies (Fig. 3) and consists of alternating Mesoproterozoic phyllites and quartzites with varying metamorphic degree [12]. The author [12] explained that the difference in metamorphic degree has been enhanced by contact metamorphism of the intrusion of the S-type granitic massifs. The subordinate mafic units and pegmatites have intruded the metasedimentary rocks. According to [6], the subordinate mafic rocks are dominantly dolerites and amphibolites, and are interpreted as pre-tectonic (by reference to a compressional stage at $\sim 1000 \mathrm{Ma}$ ), but have been shown to be syn to post-tectonic. The major mineral composition of the pegmatites from Gitarama to the Gatumba areas varies from
Fig. 2 Simplified geological map of Rwanda showing the major lithological subdivisions and granite-related ore deposits (modified after $[15,16]$ )

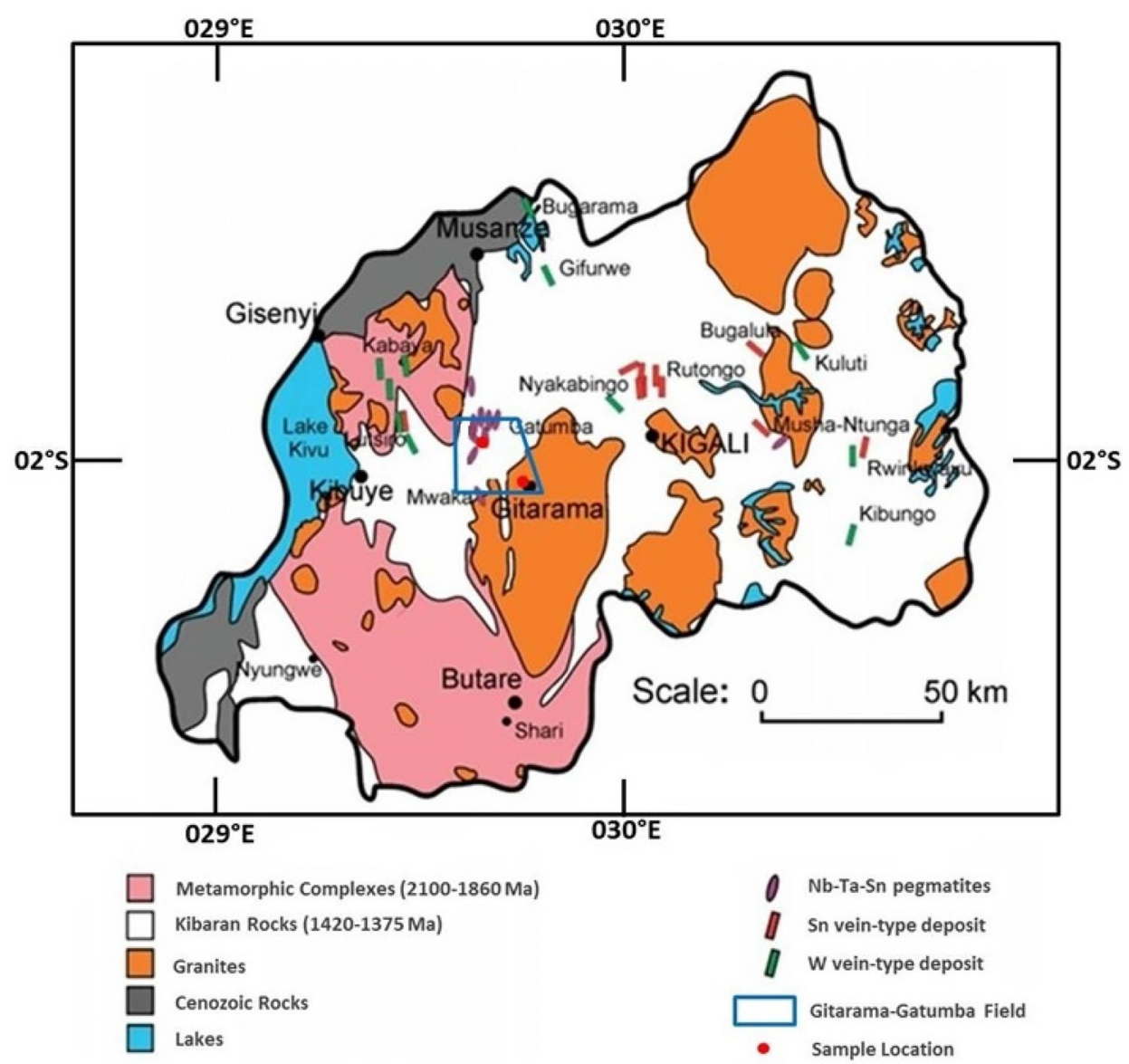


muscovite-biotite-feldspar-quartz to muscovite-feldsparquartz following the direction from Gitarama to Gatumba village [10]. The second variant appears to have been affected by intense hydrothermal alteration and $\mathrm{Nb}-\mathrm{Ta}-\mathrm{Sn}$ mineralisation [6]. Referring to the classification schemes of [13] and [14], the most evolved pegmatites belong to the Lithium-Cesium-Tantalum (LCT) family based on the rare-element association, and more specifically to the rare-element pegmatite class. Based on the rare-element mineralogy, they include representatives of the beryl-type (beryl columbite sub-type), complex-type (spodumene sub-type), and albite-spodumene type [2]. The rare-element pegmatites from the study area were found to have similar characteristics of LCT pegmatite family and attractive for geologists and mineralogists from academia.

The pegmatites from the Gatumba area can be observed inside the granitic batholiths enclosed in metasedimentary country rocks, and these intrusions are endoexo pegmatites [2]. The results of field investigation and existing geological data are integrated into the geological map of Gitarama and Gatumba areas (Fig. 3). The batholith feature consists of two types of granites: the first is a two mica-granite that shows mylonitic foliation, and the second type is a leucogranite [5]. This leucogranite contains dominant minerals of quartz-feldspar graphic intergrowths, and white mica. It clearly crosscuts and thus post-dates the foliated granite $[2,5]$. The investigation of the pegmatite zonation showed the biotite pegmatites occur exclusively as endo-pegmatites in the cupola at the roof of the Gitarama batholith. The biotite-muscovite pegmatite and the muscovite-pegmatite, which occur as endo-pegmatites, are also abundant in the metasedimentary rocks in the study area.

\section{Materials and methods}

Field and petrographic investigations were carried out to understand in detail the mineral assemblages, alteration and paragenetic relationships. Samples were first described macroscopically, and a preliminary paragenetic sequence was reconstructed. Thin sections of rock samples were prepared for petrographic study at the Department of Geology, University of Ibadan, Ibadan, Nigeria. The representative thin sections were chosen and observed with a transmitted polarised light microscope. The microtextural relations and mineral chemistry were investigated using Back Scattered Electron (BSE) and Electron Probe Micro-Analyser (EPMA). The BSE images were taken using BSE detector attached to

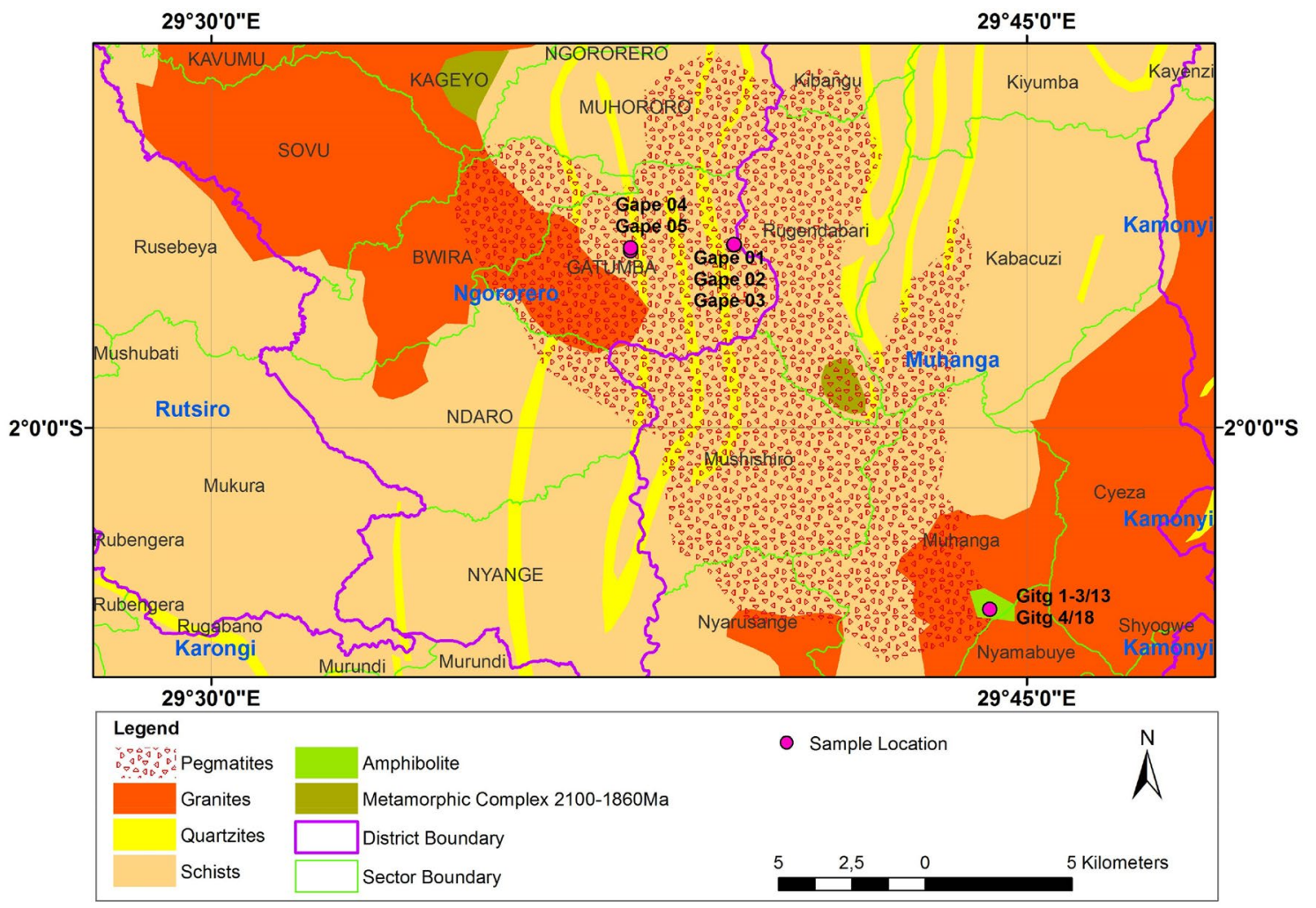

Fig. 3 Geological map of the study area, showing the granites assumed to be the parent rocks for the mineralised Gatumba pegmatites (modified after [11]) 

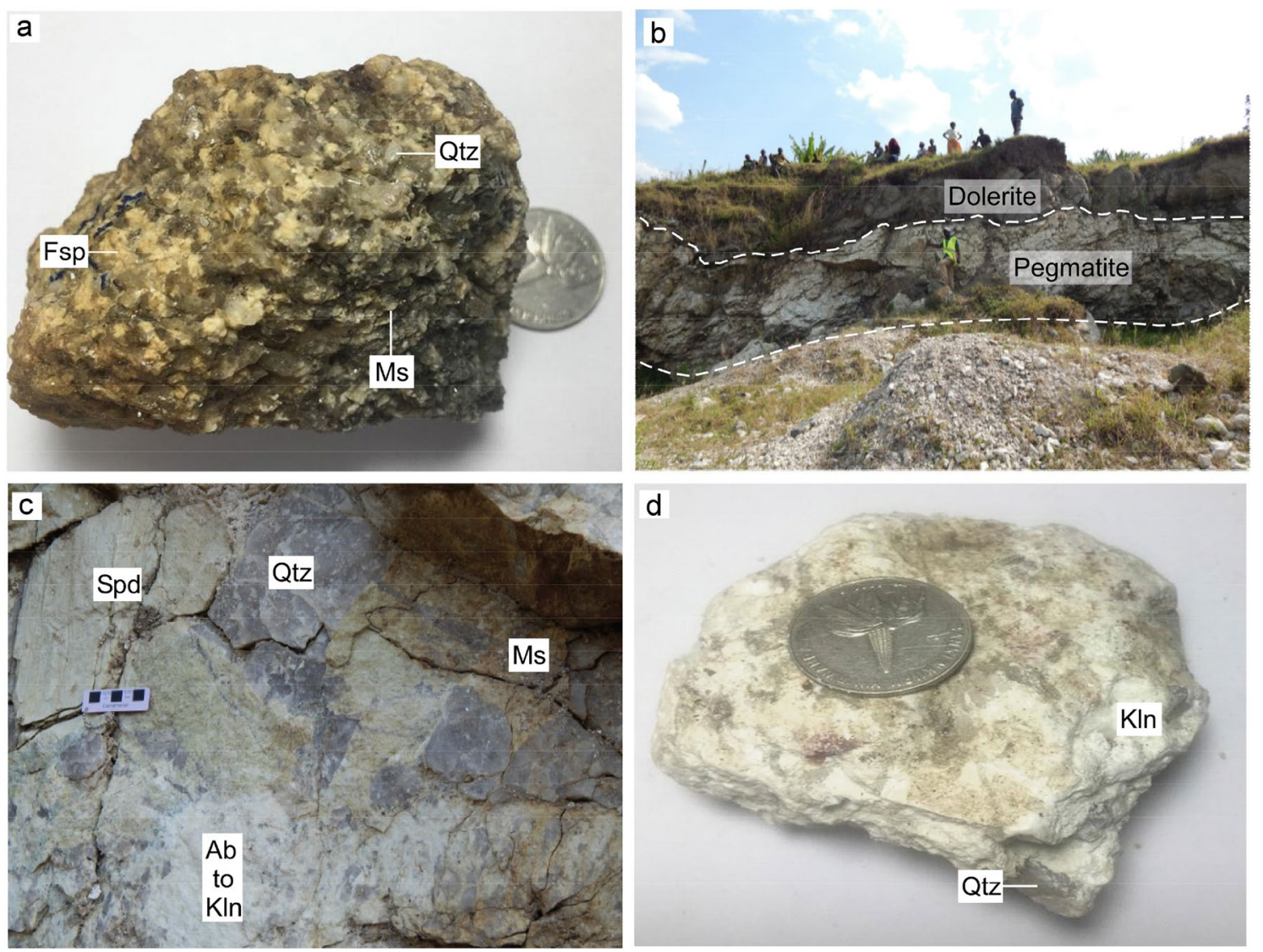

Fig. 4 a A hand specimen of Gitarama leucogranite assumed to be parent rock for the mineralised Gatumba pegmatite; $\mathbf{b}, \mathbf{c}$ These are two field photos of the Gatumba pegmatite showing the pegmatite intrusion and its progressive alteration; $\mathbf{d} \mathrm{A}$ hand specimen of

the kaolinised pegmatite found to host the $\mathrm{Nb}-\mathrm{Ta}-\mathrm{Sn}$ concentrates in the Gatumba area, Karagwe Ankole Belt. Mineral abbreviations: Fsp: Feldspar, Bt: Biotite, Qtz: Quartz, Ms: Muscovite, Ab: Albite, KIn: Kaolinite, Spd: Spodumene
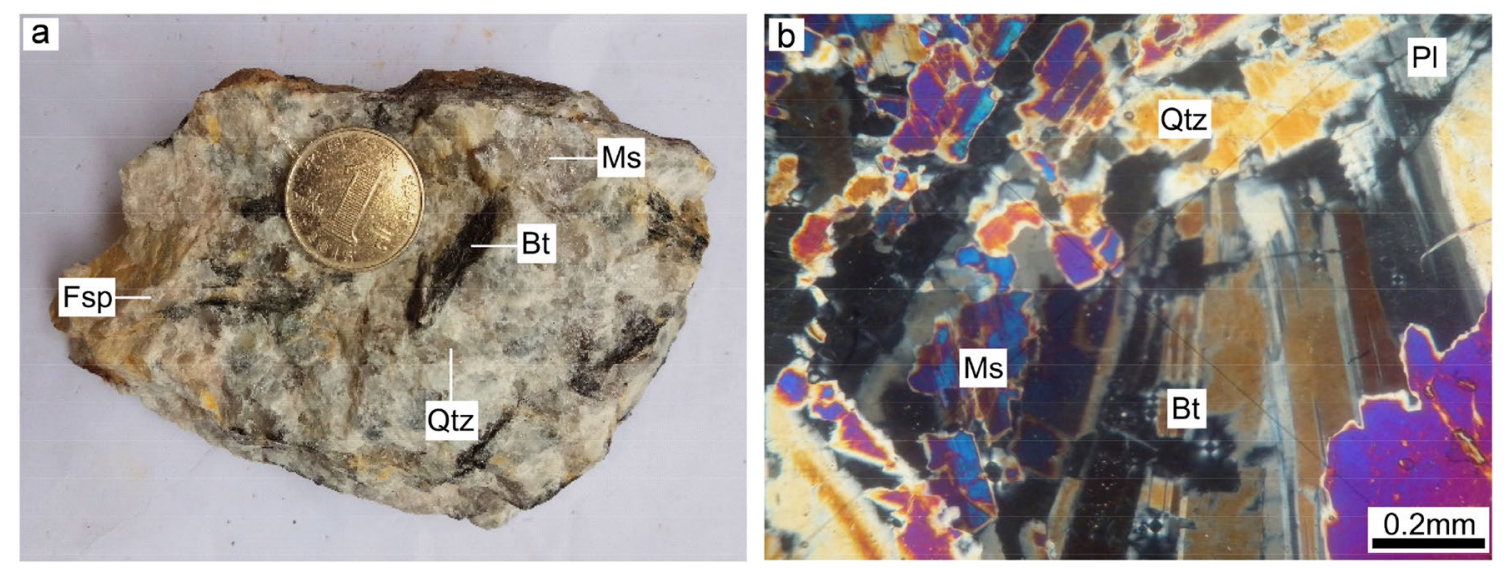

Fig. 5 a Hand specimen of pegmatite from the Gatumba area, showing the mineral texture and interlocking minerals of feldspar, muscovite, quartz and biotite; b Photomicrograph of Gatumba pegmatite (under crossed nicols) showing the dominant musco-

vites of late phase products by the alteration and filling the interstitial space between primary minerals. Mineral abbreviations: Fsp: Feldspar, Bt: Biotite, Qtz: Quartz, Ms: Muscovite 

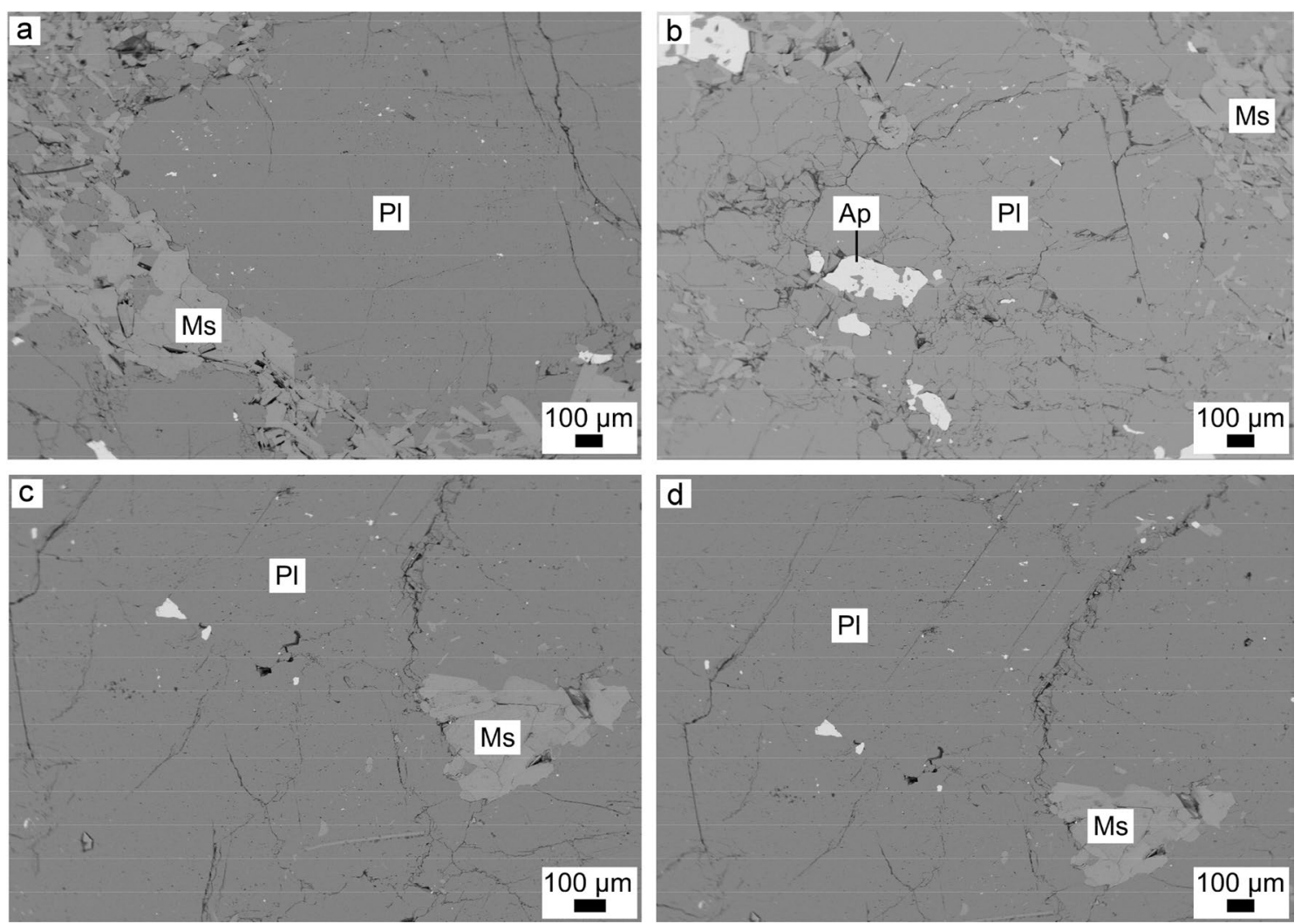

Fig. 6 Back Scattered Electron images for the minerals of pegmatite from the Gatumba area: a The pegmatite with dominant muscovites in irregular shape and form a rim around the primary plagioclase; $\mathbf{b}$ Pegmatite composed of muscovite and plagioclase with apatite as accessory mineral known as a rare constituent of kaolin-

ised pegmatite; c-d The pegmatite showing dominant plagioclase and resulted muscovite by alteration reactions occurred in reaction environment. Mineral abbreviations: Pl: Plagioclase, Ms: Muscovite, Ap: Apatite

the EPMA model JEOL JXA 8230 housed in the Advanced Facility for Microscopy and Microanalysis (AFMM), Indian Institute of Science, Bangalore, India. Mineral compositional analyses, using the same EPMA, were carried out on the diamond polished and carbon-coated thin sections. The EPMA applied analytical conditions include acceleration voltage of $15 \mathrm{kV}$, probe current of $12 \mathrm{nA}$, and electron beam size of $3 \mu \mathrm{m}$. Natural mineral standards were used for the calibration. The data were processed using the oxide-ZAF correction.

\section{Results}

\subsection{Field investigation}

Field work was carried out and revealed the outcrops with exposures of leucogranite (Fig. 4a) assumed to be the parent rock for the mineralised Gatumba pegmatite,

which has intruded older metasedimentary rocks in Gitarama towards Gatumba mine concession. The study area shows bimodal magmatism occurrence (felsic and subordinate mafic units) with dolerite (Fig. 4b) and granitic pegmatite intrusion under extensional regime. The pegmatite from the Gatumba area appears to have been affected by intense hydrothermal alteration and $\mathrm{Nb}-\mathrm{Ta}-\mathrm{Sn}$ mineralisation $[6,17]$. Albite is a precursor to kaolinite (Fig. 4c, d), which is abundant in the altered pegmatite from the study area. Muscovite has also been observed in highly fractionated pegmatite rocks in the Gatumba area.

\subsection{Petrography}

The pegmatite from the Gatumba area is composed of quartz, feldspar, biotite and muscovite (Fig. 5a). Muscovite is particularly abundant. The percentage of mineral composition shows muscovite (65\%), Biotite (15\%), Plagioclase (10\%) and Quartz (10\%). Plagioclases show the banding 
Table 1 Mineral chemistry results in weight percentage (wt\%) by Electron Micro-Probe Analysis and calculated cations for the Plagioclase from pegmatite of the Gatumba area, Karagwe Ankole Belt

\begin{tabular}{|c|c|c|c|c|c|c|c|c|c|c|}
\hline & 1 & 2 & 3 & 4 & 5 & 6 & 7 & 8 & 9 & 10 \\
\hline $\mathrm{SiO}_{2}$ & 68.44 & 68.46 & 68.26 & 69.01 & 68.43 & 68.06 & 68.26 & 68.77 & 68.40 & 68.08 \\
\hline $\mathrm{TiO}_{2}$ & bdl & bdl & bdl & 0.08 & 0.01 & 0.03 & 0.02 & bdl & bdl & bdl \\
\hline $\mathrm{Al}_{2} \mathrm{O}_{3}$ & 19.38 & 19.29 & 19.58 & 19.44 & 19.57 & 19.60 & 20.09 & 19.52 & 19.41 & 19.86 \\
\hline $\mathrm{Cr}_{2} \mathrm{O}_{3}$ & 0.05 & 0.01 & 0.04 & bdl & 0.03 & 0.04 & 0.01 & bdl & bdl & bdl \\
\hline $\mathrm{Fe}(\mathrm{O})^{\mathrm{t}}$ & bdl & 0.07 & 0.03 & 0.01 & bdl & 0.05 & 0.04 & 0.04 & 0.02 & bdl \\
\hline $\mathrm{MnO}$ & bdl & bdl & 0.02 & 0.04 & bdl & bdl & bdl & 0.01 & 0.03 & 0.02 \\
\hline $\mathrm{MgO}$ & bdl & bdl & bdl & 0.01 & bdl & 0.03 & 0.01 & bdl & bdl & bdl \\
\hline $\mathrm{CaO}$ & 0.02 & 0.01 & 0.05 & 0.02 & 0.02 & 0.09 & 0.09 & 0.03 & 0.01 & 0.08 \\
\hline $\mathrm{Na}_{2} \mathrm{O}$ & 11.29 & 11.48 & 11.19 & 11.43 & 11.51 & 11.41 & 11.44 & 11.48 & 11.50 & 11.49 \\
\hline $\mathrm{K}_{2} \mathrm{O}$ & 0.08 & 0.07 & 0.08 & 0.09 & 0.06 & 0.08 & 0.09 & 0.08 & 0.07 & 0.08 \\
\hline $\mathrm{ZnO}$ & bdl & 0.08 & 0.03 & bdl & bdl & 0.14 & 0.04 & bdl & bdl & bdl \\
\hline Total & 99.26 & 99.47 & 99.28 & 100.13 & 99.63 & 99.53 & 100.09 & 99.93 & 99.44 & 99.61 \\
\hline \multicolumn{11}{|c|}{ Structural formulae calculated based on 8 No. of oxygen } \\
\hline \multicolumn{11}{|c|}{ Cations } \\
\hline Si & 3.019 & 3.013 & 3.013 & 3.018 & 3.003 & 2.995 & 2.984 & 3.011 & 3.007 & 2.987 \\
\hline $\mathrm{Ti}$ & 0.000 & 0.000 & 0.000 & 0.003 & 0.000 & 0.001 & 0.001 & 0.000 & 0.000 & 0.000 \\
\hline Al & 1.008 & 1.000 & 1.019 & 1.002 & 1.012 & 1.017 & 1.035 & 1.007 & 1.006 & 1.027 \\
\hline $\mathrm{Cr}$ & 0.002 & 0.000 & 0.001 & 0.000 & 0.001 & 0.001 & 0.000 & 0.000 & 0.000 & 0.000 \\
\hline $\mathrm{Fe}$ & 0.000 & 0.003 & 0.001 & 0.000 & 0.000 & 0.002 & 0.001 & 0.002 & 0.001 & 0.000 \\
\hline$M n$ & 0.000 & 0.000 & 0.001 & 0.002 & 0.000 & 0.000 & 0.000 & 0.000 & 0.001 & 0.001 \\
\hline $\mathrm{Mg}$ & 0.000 & 0.000 & 0.000 & 0.001 & 0.000 & 0.002 & 0.001 & 0.000 & 0.000 & 0.000 \\
\hline $\mathrm{Ca}$ & 0.001 & 0.001 & 0.002 & 0.001 & 0.001 & 0.004 & 0.004 & 0.001 & 0.001 & 0.004 \\
\hline $\mathrm{Na}$ & 0.966 & 0.980 & 0.958 & 0.969 & 0.979 & 0.974 & 0.970 & 0.974 & 0.980 & 0.977 \\
\hline K & 0.004 & 0.004 & 0.005 & 0.005 & 0.003 & 0.004 & 0.005 & 0.004 & 0.004 & 0.004 \\
\hline Total & 5.000 & 5.000 & 5.000 & 5.000 & 5.000 & 5.000 & 5.000 & 5.000 & 5.000 & 5.000 \\
\hline \multicolumn{11}{|c|}{ End member } \\
\hline An & 0.10 & 0.10 & 0.30 & 0.10 & 0.10 & 0.40 & 0.40 & 0.10 & 0.10 & 0.40 \\
\hline$A b$ & 99.40 & 99.60 & 99.30 & 99.40 & 99.60 & 99.10 & 99.10 & 99.40 & 99.50 & 99.20 \\
\hline Or & 0.50 & 0.40 & 0.50 & 0.50 & 0.50 & 0.40 & 0.50 & 0.50 & 0.40 & 0.40 \\
\hline
\end{tabular}

bdl: below detection limit effect twinning; the biotites are distinguished from their brown color, moderate to high relief, parallel extinction and perfect cleavage in one direction. The muscovites are prominent to their bluish-purple colors in irregular shapes, these muscovites fill the interstitial space (Fig. 5b) between primary minerals.

\subsection{Mineral textures}

Back Scattered Electron (BSE) images for samples of pegmatites from the Gatumba area show the dominant muscovite (Fig. 6a, b), plagioclase (Fig. 6c-d) and apatite (Fig. 6b) as accessory mineral. Muscovite is mainly distributed in and around the plagioclase. Fractures are seen, mainly within plagioclase, and cut across the grains. The BSE and EDS show the apatite, which is commonly known as a rare constituent of kaolinised pegmatite from Gatumba area. The semi-quantitative data indicate the average concentration of the present apatite of $\mathrm{P} 2 \mathrm{O} 5$ (40.44\%); $\mathrm{CaO}$ (51.33\%); $\mathrm{MnO}$ (1.73\%); F (5.68\%) suggesting that it is a fluoroapatite. 
Fig. 7 The ternary diagram AbAn-Or showing the dominant albite in composition of the plagioclase in the pegmatite from the Gatumba area

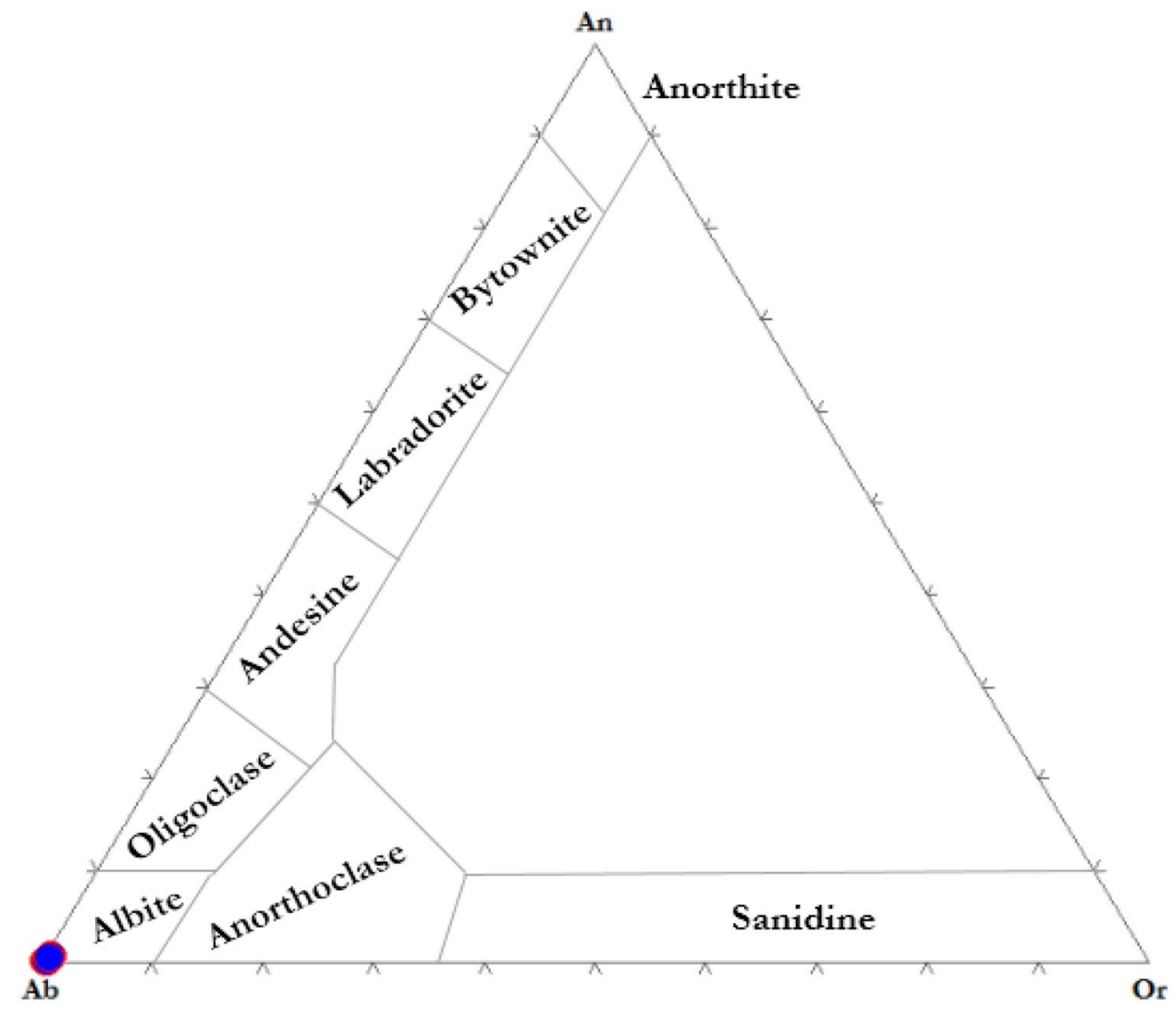

\subsection{Mineral chemistry}

\subsubsection{Plagioclase}

EPMA analysis of plagioclases reveals the concentration ranges (in wt\%) of $\mathrm{SiO}_{2}, 67.88-69.01 ; \mathrm{Na}_{2} \mathrm{O}, 11.19-11.57$ and $\mathrm{Al}_{2} \mathrm{O}_{3}, 19.16-20.09$; with low concentrations of $\mathrm{K}_{2} \mathrm{O}$; $\mathrm{TiO}_{2} ; \mathrm{MnO} ; \mathrm{MgO} ; \mathrm{CaO} ; \mathrm{Cr}_{2} \mathrm{O}_{3} ; \mathrm{FeO}(\mathrm{t}) ; \mathrm{ZnO}$ (Table 1). Plagioclase is mostly anhedral to subheudral with the end member $A n_{0.1-0.8} ; A_{98.7-99.6}$ and $\mathrm{Or}_{0.3-0.5}$ showing mainly albite in composition (Fig. 7). The feldspars are the primary minerals subsequently involved in alteration reactions, and the data attained significantly show the increase of changing to the muscovites, albites and kaolinites due to fluid compositions and variations in temperature and pressure.

\subsubsection{Muscovite}

Probed muscovites show variable concentration ranges (in wt\%) of $\mathrm{SiO}_{2}, 43.51-45.64 ; \mathrm{Al}_{2} \mathrm{O}_{3}, 33.31-35.12 ; \mathrm{FeO}$ (t), 2.61-3.62; $\mathrm{Na}_{2} \mathrm{O}, 0.65-0.75$ and $\mathrm{K}_{2} \mathrm{O}, 10.13-10.70$ (Table 2), which demonstrate the systematic variation. The obtained data plotted in Ti-Mg-Na ternary diagram (Fig. 8a, b) indicate that the analysed muscovites are of secondary types. The secondary (subsolidus) mica formation as a continuous post magmatic process follows the primary (magmatic) muscovite crystallisation. Muscovite is the most common mineralogical indicator of strongly peraluminous composition in plutonic rocks [18].

\section{Discussions}

\subsection{Alteration processes}

Field investigation shows that the mapped pegmatites are associated with granites of two types, including foliated granite and leucogranite. These granites are different in ages [8] and have different mineralogical compositions. The foliated granite $\left(G_{1-3}\right.$ granite) contains more biotites marking the foliation. The leucogranite is found weathered and researched to be younger $[2,5]$ and it has been proposed as the parental granite for the pegmatite of the Gatumba area, however, this remains a matter of debate [20]. Muscovites coexist with albite, quartz and plagioclase. The extremely low content of Ti pointing towards the post-magmatic origin, the Na content increases with progressive alteration [21]. This is suggesting the altering fluids were rich in $\mathrm{Na}$ and were constantly buffered by the pegmatitic mineral assemblage.

The weathered pegmatite has undergone albitisation, kaolinisation and muscovitisation processes resulting in 
Table 2 Mineral chemistry results in weight percentage (wt\%) by Electron Micro-

Probe Analysis and calculated cations for the Muscovite from pegmatite of the Gatumba area, Karagwe Ankole Belt

\begin{tabular}{|c|c|c|c|c|c|c|c|c|c|c|}
\hline & 1 & 2 & 3 & 4 & 5 & 6 & 7 & 8 & 9 & 10 \\
\hline $\mathrm{SiO}_{2}$ & 45.32 & 45.64 & 43.51 & 44.48 & 44.82 & 44.96 & 45.14 & 45.42 & 44.78 & 45.39 \\
\hline $\mathrm{TiO}_{2}$ & 0.02 & bdl & bdl & 0.01 & bdl & 0.05 & bdl & 0.03 & bdl & 0.02 \\
\hline $\mathrm{Al}_{2} \mathrm{O}_{3}$ & 34.98 & 34.74 & 33.31 & 34.35 & 35.12 & 34.06 & 34.08 & 34.21 & 34.47 & 34.69 \\
\hline $\mathrm{Cr}_{2} \mathrm{O}_{3}$ & 0.01 & bdl & bdl & 0.01 & bdl & bdl & bdl & bdl & bdl & bdl \\
\hline $\mathrm{Fe}(\mathrm{O})^{\mathrm{t}}$ & 2.99 & 3.01 & 2.94 & 3.14 & 2.62 & 2.92 & 3.62 & 3.13 & 2.65 & 2.84 \\
\hline $\mathrm{MnO}$ & 0.01 & bdl & 0.04 & bdl & 0.05 & bdl & 0.01 & 0.05 & bdl & bdl \\
\hline $\mathrm{MgO}$ & 0.07 & 0.12 & 0.12 & 0.09 & 0.06 & 0.12 & 0.12 & 0.13 & 0.10 & 0.13 \\
\hline $\mathrm{CaO}$ & bdl & bdl & 0.02 & bdl & 0.02 & bdl & bdl & bdl & bdl & 0.01 \\
\hline $\mathrm{Na}_{2} \mathrm{O}$ & 0.68 & 0.70 & 0.67 & 0.70 & 0.76 & 0.67 & 0.74 & 0.65 & 0.67 & 0.68 \\
\hline $\mathrm{K}_{2} \mathrm{O}$ & 10.51 & 10.45 & 10.24 & 10.68 & 10.13 & 10.70 & 10.31 & 10.62 & 10.54 & 10.60 \\
\hline $\mathrm{ZnO}$ & bdl & 0.05 & 0.01 & 0.05 & 0.04 & 0.02 & bdl & bdl & 0.02 & bdl \\
\hline Total & 94.59 & 94.71 & 90.86 & 93.51 & 93.62 & 93.50 & 94.02 & 94.24 & 93.23 & 94.36 \\
\hline \multicolumn{11}{|c|}{ Structural formulae calculated based on 11 No. of oxygen } \\
\hline \multicolumn{11}{|c|}{ Cations } \\
\hline Si & 3.070 & 3.080 & 3.070 & 3.060 & 3.060 & 3.080 & 3.080 & 3.090 & 3.070 & 3.080 \\
\hline $\mathrm{Ti}$ & 0.000 & 0.000 & 0.000 & 0.000 & 0.000 & 0.000 & 0.000 & 0.000 & 0.000 & 0.000 \\
\hline $\mathrm{Al}$ & 2.790 & 2.770 & 2.770 & 2.780 & 2.820 & 2.750 & 2.740 & 2.740 & 2.790 & 2.770 \\
\hline $\mathrm{Cr}$ & 0.000 & 0.000 & 0.000 & 0.000 & 0.000 & 0.000 & 0.000 & 0.000 & 0.000 & 0.000 \\
\hline $\mathrm{Fe}$ & 0.170 & 0.170 & 0.170 & 0.180 & 0.150 & 0.170 & 0.210 & 0.180 & 0.150 & 0.160 \\
\hline $\mathrm{Mn}$ & 0.000 & 0.000 & 0.000 & 0.000 & 0.000 & 0.000 & 0.000 & 0.000 & 0.000 & 0.000 \\
\hline $\mathrm{Mg}$ & 0.010 & 0.010 & 0.010 & 0.010 & 0.010 & 0.010 & 0.010 & 0.010 & 0.010 & 0.010 \\
\hline $\mathrm{Ca}$ & 0.000 & 0.000 & 0.000 & 0.000 & 0.000 & 0.000 & 0.000 & 0.000 & 0.000 & 0.000 \\
\hline $\mathrm{Na}$ & 0.090 & 0.090 & 0.090 & 0.090 & 0.100 & 0.090 & 0.100 & 0.090 & 0.090 & 0.090 \\
\hline $\mathrm{K}$ & 0.910 & 0.900 & 0.920 & 0.940 & 0.880 & 0.940 & 0.900 & 0.920 & 0.920 & 0.920 \\
\hline $\mathrm{Zn}$ & 0.000 & 0.000 & 0.000 & 0.000 & 0.000 & 0.000 & 0.000 & 0.000 & 0.000 & 0.000 \\
\hline Total & 7.04 & 7.02 & 7.03 & 7.06 & 7.02 & 7.04 & 7.04 & 7.03 & 7.03 & 7.03 \\
\hline
\end{tabular}

bdl: below detection limit

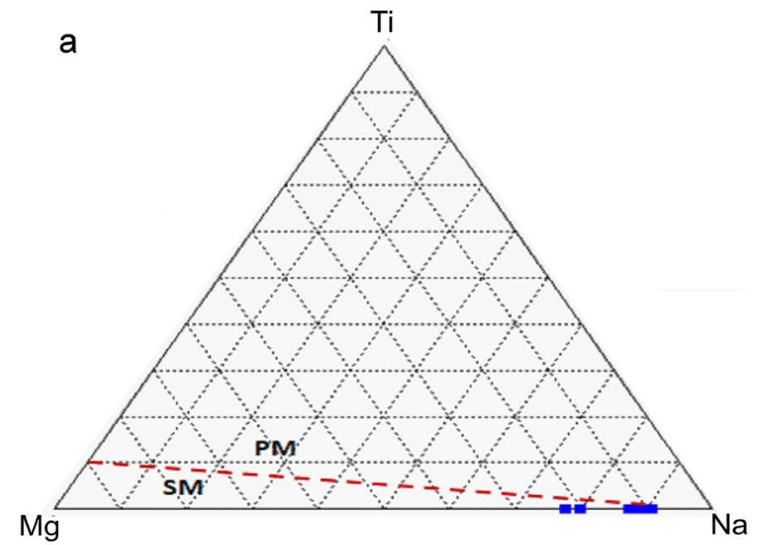

Fig. 8 Geochemical discrimination diagram for primary and secondary muscovites (PM and SM): a Ti-Mg-Na plot of muscovites in pegmatite from the Gatumba area, showing the extremely low content of Ti pointing towards the post-magmatic origin [19], the $\mathrm{Na}$ content increases with progressive alteration. b: $\mathrm{Fe} /(\mathrm{Fe}+\mathrm{Mg})$ ver-

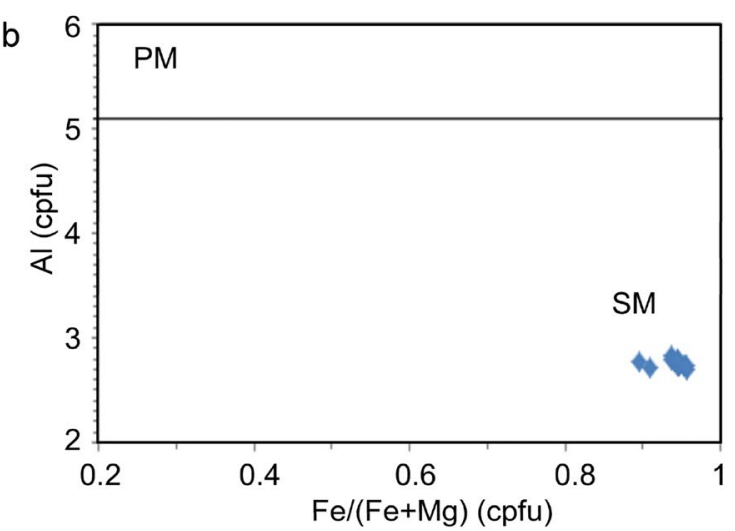

sus Al diagram of muscovites in pegmatite from the Gatumba area, showing the muscovites are higher in Fe contents indicating to be secondary types. The line dividing fields of primary and secondary muscovites (PM and SM) is inferred from [18]. cpfu = cations per formula unit 

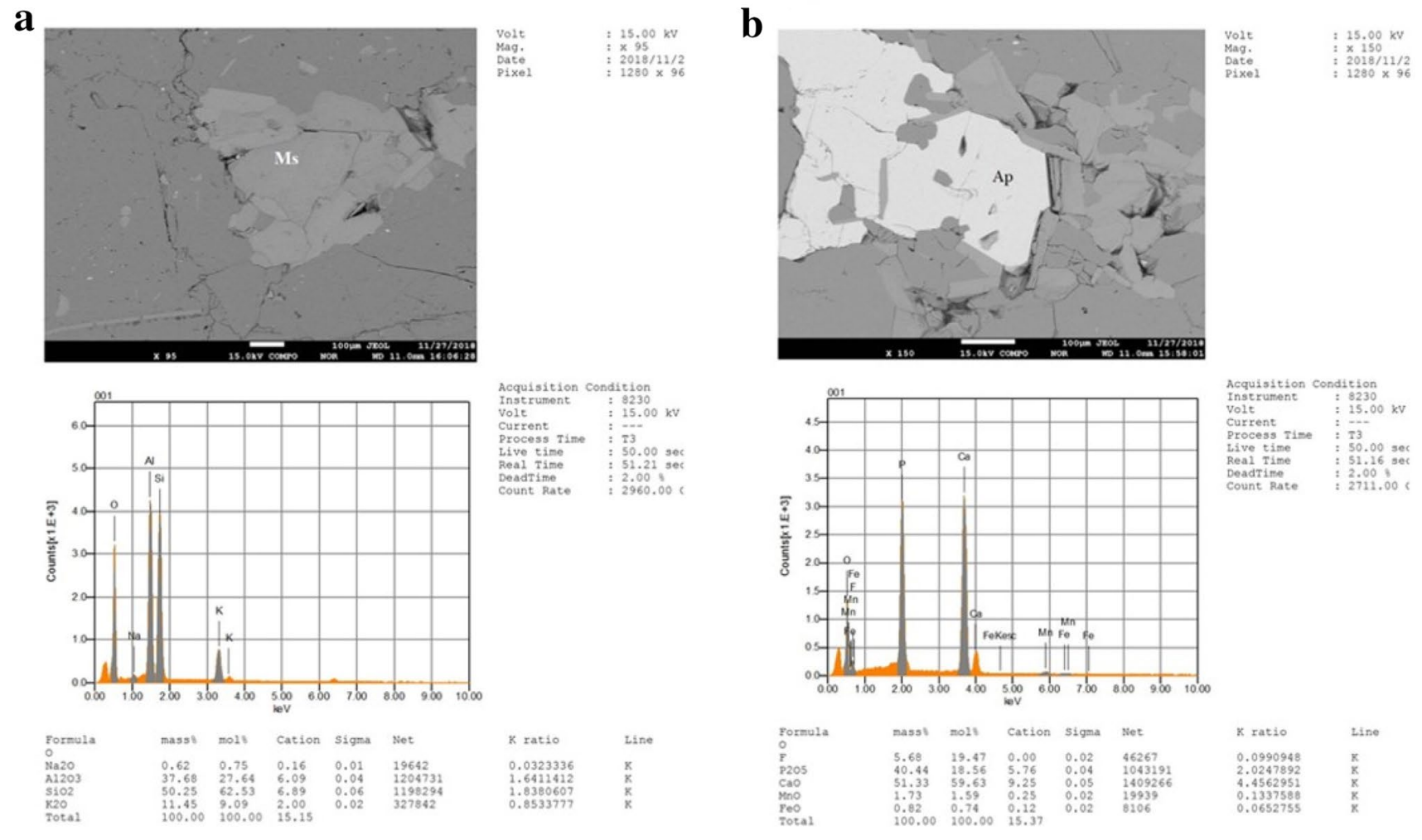

JEOL

JEOL

Fig. 9 Back Scattered Electron (BSE) and Energy-Dispersive X-ray Spectroscopy (EDS) images of muscovite (a) and apatite as an accessory mineral (b), which show the mineral textures and associated alterations in pegmatite of the Gatumba area, Karagwe Ankole Belt

Fig. 10 The diagram shows advanced argillic alteration, which accompanied the precipitation of cassiterite and columbite-tantalite in pegmatite of the Gatumba area, Karagwe Ankole Belt (modified after [22])

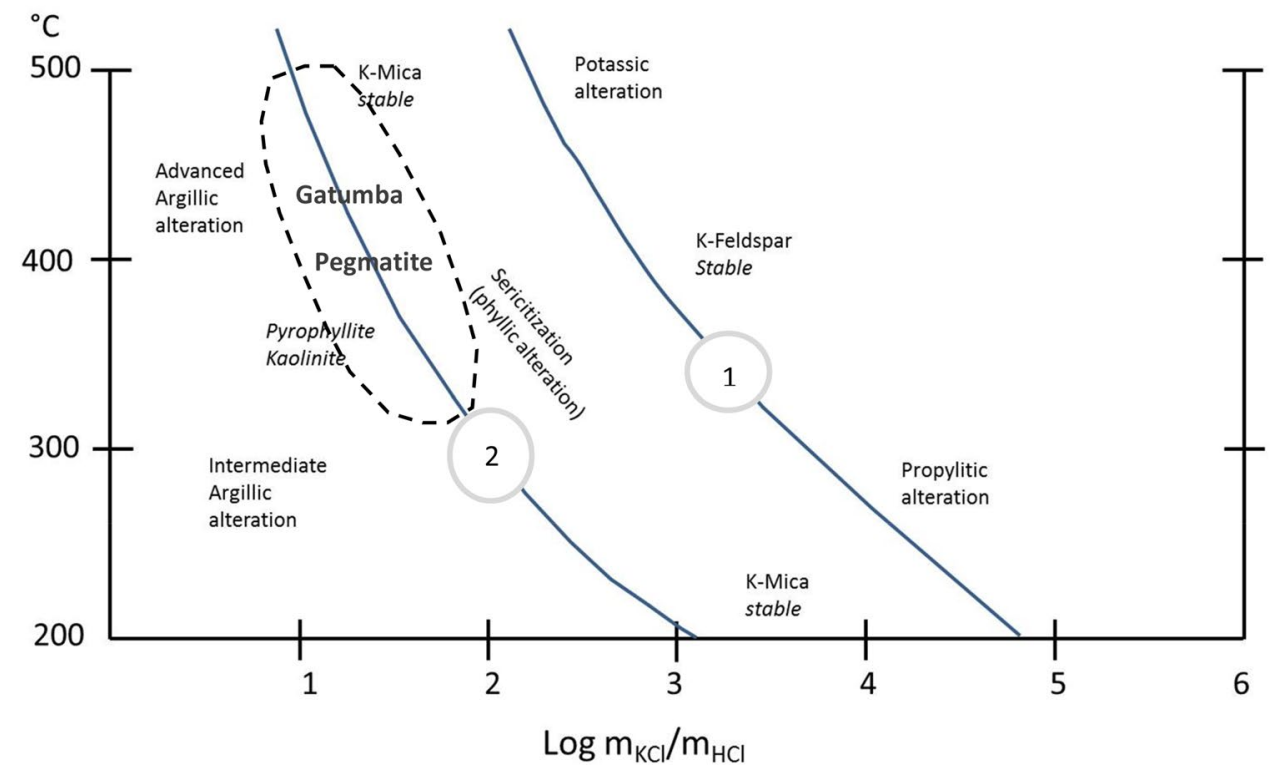


the abundance of albite, kaolinite and muscovite in its composition. The fractures of the muscovites (Fig. 9a, b) may have been caused by external stress fields. Following petrographic analysis, the following mineral reactions are believed to have occurred resulting in the present mineralogical compositions of the pegmatites. The feldspars were transformed into muscovites, and subsequently muscovites to albites and kaolinites by chemical reactions:

$$
\begin{aligned}
& 3 \mathrm{KAISi}_{3} \mathrm{O}_{8}+2 \mathrm{H}^{+} \rightarrow \mathrm{KAl}_{3} \mathrm{Si}_{3} \mathrm{O}_{10}(\mathrm{OH})_{2}+2 \mathrm{~K}^{+}+6 \mathrm{SiO}_{2} \\
& 2 \mathrm{KAI}_{3} \mathrm{Si}_{3} \mathrm{O}_{10}(\mathrm{OH})_{2}+2 \mathrm{H}^{+} \rightarrow 3 \mathrm{Al}_{2} \mathrm{Si}_{2} \mathrm{O}_{5}(\mathrm{OH})_{4}+2 \mathrm{~K}^{+}
\end{aligned}
$$

The muscovite formation could be linked to the metasomatism of feldspars during the circulation of mineralising magmatic-hydrothermal fluids. Secondary muscovites are inferred to have originated from low-temperature hydrothermal processes compared with the late to post magmatic muscovites [22]. The reactions are preferred by the movement of fluids in host rocks of the pegmatites. The process of advanced argillic alteration occurred at $300-500{ }^{\circ} \mathrm{C}$ (Fig. 10) resulted in an abundance of white minerals of kaolinites in the pegmatite of the Gatumba area.

\subsection{Implications for $\mathrm{Nb}-\mathrm{Ta}-\mathrm{Sn}$ mineralisation}

Geochemistry studies of Feldspar and Muscovite from pegmatite of the Gatumba area show a link to the $\mathrm{Nb}-\mathrm{Ta}-\mathrm{Sn}$ mineralisation. Kaolinisation was found as a tool to alter the primary emplaced pegmatite which released the $\mathrm{Nb}-\mathrm{Ta}$, $\mathrm{Sn}$ rare metals precipitated into columbite-tantalite and cassiterite [23]. Cassiterite overprinted the columbite-tantalite in granitic pegmatites by precipitation reactions. Columbite-tantalite (Coltan) occurs in granitic pegmatites, pockets where the deep-seated molten rocks undertook late crystallisation to form $\mathrm{Me}(\mathrm{II})(\mathrm{Nb}, \mathrm{Ta})_{2} \mathrm{O}_{6}$ more stable than other compounds of the type $\mathrm{Me}(\mathrm{II})(\mathrm{Nb}, \mathrm{Ta}) \mathrm{O}_{2} \mathrm{O}_{7}$ and $\mathrm{Me}$ (IV) $(\mathrm{Nb}, \mathrm{Ta}) \mathrm{O}_{2} \mathrm{O}_{9}$, which are probably thermodynamically unstable at elevated temperatures, and will decompose into $\mathrm{Me}(\mathrm{Nb}, \mathrm{Ta})_{2} \mathrm{O}_{6}$ and $\mathrm{MeO} . \mathrm{Me}=$ Transition metal [24].

$$
\begin{aligned}
\mathrm{Sn}(\mathrm{II}) \mathrm{Cl}_{x}^{2-x} \text { (aqueous) }+2 \mathrm{H}_{2} \mathrm{O}= & \mathrm{Sn}(\mathrm{IV}) \mathrm{O}_{2} \text { (Cassiterite) } \\
& +2 \mathrm{H}^{+}+x \mathrm{Cl}^{-}+\mathrm{H}_{2} \mathrm{O}
\end{aligned}
$$

The abundance of muscovites suggests that there is high fractionation of strong incompatible trace elements such as $\mathrm{F}, \mathrm{Li}, \mathrm{Be}, \mathrm{B}, \mathrm{Rb}, \mathrm{Cs}$, Ta and $\mathrm{Sn}$ in the magma melts culminated into the $\mathrm{Nb}-\mathrm{Ta}-\mathrm{Sn}$ pegmatites hosting columbite-tantalite and cassiterite ores in the Gatumba mine concession.

\section{Conclusions}

The studies including field investigation, petrographic and mineral chemistry analyses were used to unravel the mineralisation and alteration processes in pegmatites from the Gatumba area. The presence of quartz and the dominance of secondary muscovite together with albite precursor to kaolinite indicate that the processes of muscovitisation and albitisation to kaolinisation are potentially linked with the $\mathrm{Nb}-\mathrm{Ta}-\mathrm{Sn}$ mineralisation of the pegmatite in the Gatumba area. Alteration occurred as a tool to alter the primary emplaced pegmatites, while releasing the $\mathrm{Nb}-\mathrm{Ta}$ and Sn rare metals precipitated into columbite-tantalite and cassiterite. This work shows that the Gatumba area is the district of interest for the study of rare-element pegmatites in the Karagwe Ankole Belt, which hosts the Mesoproterozoic to Neoproterozoic granite-related ore deposits.

Acknowledgements The African Union Commission is appreciated for granting scholarship and Research Grant to Jean de Dieu Ndikumana for this intended work. Rwanda Mines, Petroleum and Gas Board (RMB) is acknowledged for providing the permission to collect and export samples to the laboratories for analyses. Anonymous reviewers and editor whose comments improved this manuscript are highly appreciated.

Funding This study is funded by African Union Commission (Matric number: PAU-UI-0245).

\section{Compliance with ethical standard}

Conflict of interest Authors declare that there is no potential conflict of interest.

\section{References}

1. Fernandez-Alonso $M$, Cutten $H$, De Waele B, Tack L, Tahon A, Baudet D, Barritt SD (2012) The Mesoproterozoic KaragweAnkole Belt (formerly the NE Kibara Belt): the result of prolonged extensional intracratonic basin development punctuated by two short-lived far-field compressional events. Precambrian Res 216:63-86

2. Hulsbosch N, Hertogen J, Muchez P, André L, Dewaele S (2013) Trace element evolution, REE patterns and crystal/melt modelling of the $\mathrm{Nb}-\mathrm{Ta}-\mathrm{Sn}$ mineralised Gatumba pegmatite field (Rwanda). Socr Geol Appl Minl Depos 16:105-117

3. Nambaje C, Eggins SM, Yaxley GM, Sajeev K (2020) Micro-characterisation of cassiterite by geology, texture and zonation: a case study of the Karagwe Ankole Belt, Rwanda. Ore Geol Rev. https://doi.org/10.1016/j.oregeorev.2020.103609 
4. Pohl WL, Biryabarema M, Lehmann B (2013) Early Neoproterozoic rare metal ( $\mathrm{Sn}, \mathrm{Ta}, \mathrm{W})$ and gold metallogeny of the Central Africa Region: a review. Appl Earth Sci 122:66-82

5. Muchez P, Hulsbosch N, Dewaele S, Wetenschappen MZKAO (2014) Geological mapping and implications for Nb-Ta, Sn and W prospection in Rwanda. Mededelingen Zittingen Koninklijke Academie Overzeese Wetenschappen 60:515-530

6. Dewaele $S$, Henjes-Kunst F, Melcher F, Sitnikova M, Burgess $R$, Gerdes A, Fernandez MA, De Clercq F, Muchez P, Lehmann B (2011) Late Neoproterozoic overprinting of the cassiterite and columbite-tantalite bearing pegmatites of the Gatumba area, Rwanda (Central Africa). J Afr Earth Sci 61:10-26

7. Tack L, Wingate MTD, De Waele B, Meert J, Belousova E, Griffin B, Tahon A, Fernandez-Alonso M (2010) The 1375 Ma "Kibaran event" in Central Africa: prominent emplacement of bimodal magmatism under extensional regime. Precambrian Res 180:63-84

8. Pohl W (1994) Metallogeny of the northeastern Kibara belt, Central Africa-Recent perspectives. Ore Geol Rev 9:105-130

9. Dewaele S, Tack L, Fernandez M, Boyce A, Muchez P (2007) Cassiterite and columbite mineralization in pegmatites of the northern part of the Kibara orogen (Central Africa): the Gatumba area (Rwanda). Irish Assoc Econ Geol Proc 2:1489-1492

10. Varlamoff N (1954) Répartition des types de pegmatites autour de la partie nord-ouest du grand massif granitique de Nyanza. Annales de la Société géologique de Belgique 78:1-21

11. Theunissen K, Hanon H, Fernandez-Alonso M (1991) Carte géologique du Rwanda, $1: 200$ 000. Service géologique, ministère de l'industrie et de l'artisanat, République Rwandaise

12. Gérards J (1965) Géologie de la région de Gatumba. Bull Serv Geol Rwanda 2:31-42

13. Černý P (1991) Rare-element granitic pegmatites. Part I: anatomy and internal evolution of pegmatitic deposits. Geoscience Canada 18(2). https://journals.lib.unb.ca/index.php/GC/article/ view/3722. Accessed 26 Aug 2020

14. Černý P, Ercit TS (2005) The classification of granitic pegmatites revisited. Can Mineral 43:2005-2026
15. Baudin B (1979) Mineralisation et inventaire des mineraux du Rwanda, tome 1. Université Nationale du Rwanda

16. Fernandez-Alonso M, Tack L, Tahon A, Laghmouch M, Hardy B (2007) Geological compilation of the Mesoproterozoic Northeastern Kibara (KaragweAnkole) Belt.-Tervuren, RMCA, 1/500 000

17. De Clercq F (2012) Metallogenesis of Sn and W vein-type deposits in the Karagwe-Ankole belt (Rwanda). Ph.D Dissertation, Katholieke Universiteit Leuven

18. Miller CF, Stoddard EF, Bradfish LJ, Dollase WA (1981) Composition of plutonic muscovite; genetic implications. Can Mineral 19:25-34

19. Speer JA (1984) Micas in igneous rocks. Reviews in mineralogy. Miner Soc Amer 13:57-368

20. Lehmann B, Halder S, Munana JR, de la Paix Ngizimana J, Biryabarema M (2013) The geochemical signature of rare-metal pegmatites in Central Africa: magmatic rocks in the Gatumba tin-tantalum mining district, Rwanda. J Geochem Explor 144:528-538

21. Konings RJ, Boland JN, Vriend SP, Jansen JBH (1988) Chemistry of biotites and muscovites in the Abas granite, northern Portugal. Am Mineral 73(7-8):754-765

22. Pabalan RT (1986) Solubility of cassiterite ( $\mathrm{SnO} 2$ ) in NaC1 solutions from $2000 \mathrm{c}-3500 \mathrm{C}$, with geologic applications. Unpub. Ph.D. thesis, Pennsylvania State Univ

23. Dill HG, Dohrmann R, Kaufhold S, Balaban SI (2015) Kaolinization - a tool to unravel the formation and unroofing of the Pleystein pegmatite-aplite system (SE Germany). Ore Geol Rev 69:33-56

24. Emmenegger F, Petermann A (1968) Transport reactions and crystal growth of transition metal niobates. J Cryst Growth 2:33-39

Publisher's Note Springer Nature remains neutral with regard to jurisdictional claims in published maps and institutional affiliations. 